\title{
Chemotaxonomic Study of Six Nigerian Ficus Species (Moraceae)
}

\author{
Olaniran T. OLADIPO ${ }^{1 *}$, Bolajoko A. AKINPELU², \\ Abayomi E. FOLORUNSO ${ }^{1}$, Anyim GODWIN ${ }^{2}$, Segun E. OMOTOSO ${ }^{2}$, \\ Oluwatosin A. DOSUNMU ${ }^{1}$, Winnie A. JOSEPH ${ }^{1}$
}

\author{
${ }^{1}$ Obafemi Awolowo University, Department of Botany Ile-Ife, Nigeri; niranoladipo.to@gmail.com ( ${ }^{*}$ corresponding author) \\ ${ }^{2}$ Obafemi Awolowo University, Ile-Ife, Department of Biochemistry, Nigeria;
}

\begin{abstract}
The current study was designed to investigate the chemical fingerprints in six Nigerian Ficus species based on the phytoconstituents for chemotaxonomic classification. The powdered leaf samples of the plants were extracted separately with absolute ethanol and chloroform and were then concentrated in vacuole to yield the crude ethanol and chloroform extracts respectively. The total flavonoid and tannin contents of each plant species were estimated via spectroscopic techniques. The results revealed the presence of tannins in chloroform and ethanol extracts of $F$. exasperata, $F$. sycomorus and chloroform extracts of $F$. glumosa, F. mucuso and $F$. vogelli. Flavonoids were present in chloroform extract of all the studied species and ethanol extract of $F$. mucuso, $F$. exasperata and $F$. sycomorus, while anthraquinone was absent in all. Also, saponins and alkaloids tested positive in F. glumosa, F. vogelli, F. cordata, F. sycomorus and F. mucuso (alkaloid absent), while steroids and triterpenes were present in F. glumosa, F. mucuso, F. vogelli and $F$. exasperata only. The presence of flavonoids, tannins, saponins, steroids and the absence of anthaquinone in all the Ficus species studied indicated that they are generic features. The study revealed that Ficus species contained valuable phytomarkers which are of pharmaceutical importance and suitable for authentication and differentiation among the studied species.
\end{abstract}

Keywords: chemotaxonomy, Ficus species, phytochemicals, TLC

\section{Introduction}

Plants synthesized a wide variety of bioactive compounds that are used in treatment of ailment in both humans and animals and this dates back to antiquity (Paulsamy and Jeeshna, 2011). The science of chemotaxonomy is used for the classification of plants on the basis of their chemical constituents which relied on the chemical similarity of taxon (Atal, 1982; Rasool et al., 2010). Three broad categories of compounds used in chemotaxonomy are primary metabolites; secondary metabolites and semantides. Primary metabolites are the compounds that are involved in the fundamental metabolic pathways (Singh, 2011).

Products of primary metabolism are usually in high volume but low value and include such substances as carbohydrates, amino acids, fatty acids and proteins which are vital for growth, development and maintenance of life processes (Rehana and Nagarajan, 2014). The products of secondary metabolism, in contrast, are usually in low volume but high value and include such substances as alkaloids, flavonoids, saponins, tannins, phenolics, steroids, terpenoids (Rehana and Nagarajan, 2014). Species in the
Moraceae family have important economic and medicinal value. Ficus species are rich sources of bioactive secondary metabolites such as flavonoids stilbenes, triterpenoids and xanthones (Ngadjui et al., 2005; Han et al., 2006; Jayasinghe et al., 2008; Lee et al., 2009). Plants produce these chemicals to protect themselves against diseases, stress and grazing but recent research demonstrates that many of such phytochemicals can protect humans against disease. But since these secondary metabolites occur in low volume, there is therefore need to screen such medicinal plant species in order to reveal their active principles and possibly isolate and characterize them. While chromatographic techniques are unavoidably important in the separation of complex herbal mixtures, thin layer chromatography (TLC) is often the first step in identifying compounds present in such samples (Karthika et al., 2014). In this present study, the phytochemical constituents of six Ficus species (Ficus exasperata, Ficus cordata, Ficus sycomorus, Ficus glumosa, Ficus mucuso and Ficus vogelii) were investigated using Thin Layer C Chromatographic (TLC) and spectroscopic techniques.

The diversity in the genus Ficus has resulted in a number of taxonomic problems leading to misidentification of the 
species. These misidentifications have gross implications for the effective use of the species for their medicinal benefits. Therefore, it is envisaged that this study will provide diagnostic chemical characters for taxonomic delimitation of each of these Ficus species.

\section{Materials and Methods}

\section{Collection of plant samples}

Plant samples of Ficus exasperata Vahl., Ficus cordata (Warb.) C.C. Berg., Ficus sycomorus L., Ficus glumosa Del., Ficus mucuso Welw. Ex. Ficalho and Ficus vogelii, (Miq). Miq. were collected from various locations at Obafemi Awolowo University (Lat $7^{\circ} 30$ and $7^{\circ} 34 \mathrm{~N}$, Long $4^{\circ} 30$ and $\left.4^{\circ} 32 \mathrm{E}\right)$ Nigeria. These plants were chosen based on their ethnomedicinal information. The plants were identified and authenticated at IFE Herbarium, Department of Botany, Obafemi Awolowo University, Ile - Ife, Nigeria. Voucher specimens were also deposited in this herbarium.

\section{Preparation of the extract}

Each plant material was air dried and milled into powder. The powdered materials (20 g each) were separately extracted with absolute ethanol or chloroform for $48 \mathrm{hrs}$ respectively and filtered. The filtrate for each sample material was concentrated in vacuole at $35^{\circ} \mathrm{C}$ to yield the ethanol and chloroform extracts of each sample.

\section{Phytochemical screening}

The standard methods of (Trease and Evans, 2002) and (Sofowora, 2006) were adopted for phytochemical screening of the plant extracts. Alkaloids (Mayer's, Wagner's and Dragendorf reagents), saponins (froth test), flavonoids (ethanolic $\mathrm{KOH} /$ ethylacetate), cardiac glycosides (chloroform/ $\mathrm{H}_{2} \mathrm{SO}_{4}$ ), tannins (ferric chloride reagent), xanthoprotein (dilute $\mathrm{H}_{2} \mathrm{SO}_{4}$ /benzene /ammonia solution), anthraquinones (ethanolic $\mathrm{NaOH}$ ), phlabotannins $\left(\mathrm{HNO}_{3} /\right.$ ammonia solution), triterpenes (chloroform/conc. $\mathrm{H}_{2} \mathrm{SO}_{4}$ ) and steroids (conc. $\mathrm{H}_{2} \mathrm{SO}_{4}$ ).

\section{Estimation of tannins content}

Tannic acid standard method (Van-Burden and Robinson, 1981) was adopted for the estimation of total tannin contents. The reaction mixture, consisted of extract $(0.2 \mathrm{ml}), 0.2 \mathrm{ml}$ ammonium ferric citrate $(3.5 \mathrm{~g} / \mathrm{l})$ and 0.2 $\mathrm{ml}$ of $20 \%(\mathrm{v} / \mathrm{v})$ ammonia, was incubated for $15 \mathrm{~min}$ at room temperature. The absorbance was read at $500 \mathrm{~nm}$ against the reagent blank. The concentration of tannins in the extract was extrapolated from the standard curve and expressed as milligram tannic acid equivalent per $g$ of extract (mgTAE/g extract).

\section{Total flavonoids content}

Aluminum chloride reaction method (Sun et al., 1999) was adopted for the estimation of total flavonoid concentration. The reaction mixtures consisted of extract $(0.2 \mathrm{ml})$ in ethanol, distilled water $(2.8 \mathrm{ml}), 5 \%(\mathrm{w} / \mathrm{v})$ $\mathrm{NaNO}_{2}(0.3 \mathrm{ml}), 10 \%(\mathrm{w} / \mathrm{v}) \mathrm{AlCl}_{3}(0.3 \mathrm{ml})$ and $4 \%(\mathrm{w} / \mathrm{v})$ $\mathrm{NaOH}(4 \mathrm{ml})$. The reaction mixture was allowed to stand for $15 \mathrm{~min}$ and absorbance was read at $500 \mathrm{~nm}$. The flavonoid content of the extracts was expressed as $\mathrm{mg} / \mathrm{g}$ (QE) Quercetin equivalent.

\section{Thin layer chromatographic analysis}

The ethanol and chloroform extracts of the six Ficus species were manually spotted using capillary tubes on precoated TLC Silica gel plates 60 F254 (MERCK, Germany) $(20 \times 20 \mathrm{~cm}$ with $0.2 \mathrm{~mm}$ thickness (Wagner $e t$ al., 1996). The plates were activated at $105^{\circ} \mathrm{C}$ for $15 \mathrm{~min}$ and then transferred into a chromatography tank already saturated with appropriate solvent systems. After the separation of phytochemical constituents, the spraying reagents such as Dragendorff reagent, 1\% aluminium chloride, $1 \%$ ferric chloride, $50 \%$ vanillin sulfuric acid and $70 \%$ sulphuric-acetic acid in ethanol were used to identified alkaloids, flavonoid, tannins, saponin and steroid respectively. The retardation factor (Rf) was calculated from the equation:

\section{$\operatorname{Retardation}$ factor $(\mathrm{Rf})=$}

Distance moved by solute/Distance moved by solvent

\section{Results}

The results of phytoconstituents of chloroform and ethanolic leaf extracts of six Ficus species are as shown in Table 1. All the studied Ficus plants tested positive for flavonoids, tannins, saponins and steroids. However, anthraquinone was absent in all the plant samples; alkaloids were specific to $F$. glumosa, $F$. vogelli, $F$. cordata and $F$. sycomorus while triterpenes were present in $F$. glumosa, $F$. mucuso, $F$. vogelli and $F$. exasperata. Cardiac glycosides tested positive in $F$. mucuso, $F$. vogelli, $F$. exasperata and $F$. sycomorus while $F$. cordata, $F$. vogelli, and $F$. exasperata tested positive for xanthoproteins. Phlobatannins was present only in F. vogelli and F. sycomorus.

TLC fingerprints (Fig. 1) confirmed the presence of various phytochemicals in the studied Ficus species, as indicated in Table 1, after spraying with appropriate reagents (Table 2). Different $\mathrm{Rf}$ values (Table 3 ) were produced by different phytochemicals in different solvent system. Alkaloid with Rf value 0.88 is peculiar to $F$. vogelli, $F$. sycomorus, for flavonoids, while species like $F$. vogelli, $F$. glumosa, F. cordata and $F$. sycomorus all show congruence in having similar spots at Rf 0.70 and 0.80 . Similar pattern of relationship is observed in the types of tannins, saponins and steroids with only few exceptions.

Quantitative analysis of flavonoids and tannins contents in the leaves of the studied Ficus species are as shown in Table 4. It was observed that chloroform extracted flavonoid better in all the studied Ficus species except for $F$. cordata and $F$. vogelli while ethanol showed a better solvent of extraction for tannin with exception of $F$. mucuso. The highest total flavonoid and tannins content were found in chloroform extracts of $F$. glumosa and $F$. mucuso respectively. Figures $2 \mathrm{a}$ and $2 \mathrm{~b}$ show the extent of relationship among the Ficus species based on the ethanolic and Choroform extracts. The Ficus species were clustered differently based on the phytoconstituent as well as on the basis of types of extracts. 
252

Table 1. Phytochemicals constituents of chloroform and ethanolic leaf extracts of different Ficus species

\begin{tabular}{|c|c|c|c|c|c|c|c|c|c|c|}
\hline & Tannins & $\begin{array}{l}\text { Flavo- } \\
\text { noids }\end{array}$ & Saponins & Steroids & $\begin{array}{l}\text { Cardiac } \\
\text { glycosides }\end{array}$ & $\begin{array}{l}\text { Phloba- } \\
\text { tannins }\end{array}$ & $\begin{array}{l}\text { Anthro- } \\
\text { quinone }\end{array}$ & $\begin{array}{l}\text { Triter- } \\
\text { penes }\end{array}$ & Alkaloids & $\begin{array}{l}\text { Xantho- } \\
\text { proteins }\end{array}$ \\
\hline F. glumosa ${ }^{\mathrm{EE}}$ & - & - & - & - & - & - & - & + & - & - \\
\hline F. glumosa ${ }^{\mathrm{CE}}$ & + & + & + & + & - & - & - & + & + & - \\
\hline F. mucuso ${ }^{\mathrm{EE}}$ & - & + & + & - & + & - & - & + & - & - \\
\hline F. mucuso ${ }^{\mathrm{Cz}}$ & + & + & + & + & + & - & - & + & - & - \\
\hline F. vogelli ${ }^{\mathrm{EE}}$ & - & - & - & - & + & + & - & + & + & + \\
\hline F. vogelli ${ }^{\mathrm{CE}}$ & + & + & + & + & - & + & - & - & - & - \\
\hline F. exasperata ${ }^{\mathrm{EE}}$ & + & + & + & + & - & - & - & - & - & - \\
\hline F. exasperata ${ }^{C E}$ & + & + & + & + & + & - & - & + & - & + \\
\hline F. cordata $^{\mathrm{EE}}$ & - & - & - & + & - & - & - & - & + & - \\
\hline F. cordata $^{\mathrm{CE}}$ & - & + & + & + & - & - & - & - & - & + \\
\hline F. sycomorus ${ }^{\mathrm{EE}}$ & + & + & - & - & - & - & - & - & + & - \\
\hline F. sycomorus ${ }^{\mathrm{CE}}$ & + & + & + & + & + & + & - & - & - & - \\
\hline
\end{tabular}

Table 2. Solvent system/spraying reagent used in chromatographic procedure of Ficus leaf extracts

\begin{tabular}{ccccc}
\hline $\mathrm{S} / \mathrm{N}$ & $\begin{array}{c}\text { Secondary } \\
\text { metabolites }\end{array}$ & Solvent system & Solvent ratio & Spraying reagent \\
\hline 1 & Alkaloids & EtOAc:MeOH:H$: \mathrm{H}_{2} \mathrm{O}$ & $10: 1.4: 1$ & Dragendorff \\
2 & Flavonoids & Toluene:Acetone:Formic acid & $4.5: 4.5: 1.0$ & $1 \% \mathrm{Ethanolic} \mathrm{AlCl}_{3}$ \\
3 & Tannins & EtOAc:Formic acid:MeOH & $3: 3: 0.8: 0.2$ & $5 \% \mathrm{FeCl}_{3}$ \\
4 & Saponins & Chloroform:MeOH & $1.2: 0.2$ & $50 \%{\mathrm{Vanillin} \mathrm{H}_{2} \mathrm{SO}_{4}}$ \\
5 & Steroids & Hexane: EtOAc & $7.2: 2.9$ & $70 \% \mathrm{H}_{2} \mathrm{SO}_{4}$-Acetic acid in ethanol \\
\hline
\end{tabular}

EtOAc - Ethylacetate; $\mathrm{MeOH}$ - Methanol; "-“: Absent; "+": Present; EE: Ethanol Extract; CE: Chloroform extract

Table 3. Rf values of TLC solvent systems for leaf extract of different Ficus species

\begin{tabular}{|c|c|c|c|c|c|}
\hline & Alkaloids & Flavonoids & Tannins & Saponins & Steroids \\
\hline F. glumosa ${ }^{E E}$ & - & - & - & - & - \\
\hline F. glumosa ${ }^{\mathrm{CE}}$ & 1.00 & $0.70,0.84$ & $0.7,0.80$ & $0.43,0.75$ & $0.09,0.22,0.49$ \\
\hline F. mucuso $o^{\mathrm{EE}}$ & - & - & 0.25 & - & \\
\hline F. mucuso ${ }^{\mathrm{CE}}$ & - & $0.72,0.88$ & $0.38,0.43,0.50,0.68$ & $0.43,0.50,0.68$ & $0.09,0.22,0.53,0.78$ \\
\hline F. vogelli ${ }^{\mathrm{EE}}$ & 0.88 & - & - & - & \\
\hline F. vogelli $\mathrm{CE}$ & - & $0.64,0.86$ & 0.94 & $0.38,0.40,0.50,0.66$ & $0.09,0.22,0.80$ \\
\hline F. exasperata ${ }^{\mathrm{EE}}$ & - & $0.58,0.70$ & 0.25 & - & 0.01 \\
\hline F. exasperata ${ }^{\mathrm{CE}}$ & - & $\begin{array}{c}0.40,0.58,0.60,0.70 \\
0.78,0.86\end{array}$ & $0.15,0.50,0.70,0.80$ & $0.35,0.40,0.50,0.68$ & $0.07,0.20,0.56$ \\
\hline F. cordata $^{\mathrm{EE}}$ & - & - & - & & - \\
\hline F. cordata ${ }^{\mathrm{CE}}$ & $0.12,0.85,0.97$ & $\begin{array}{c}0.44,0.60,0.70,0.80 \\
0.86\end{array}$ & $\begin{array}{c}0.25,0.27,0.38,0.40 \\
0.50,0.60\end{array}$ & $\begin{array}{c}0.38,0.45,0.55,0.63 \\
0.70\end{array}$ & 0.22 \\
\hline F. sycomorus $^{\mathrm{EE}}$ & 0.88 & 0.56 & - & - & - \\
\hline F. sycomorus $\mathrm{CE}^{\mathrm{CE}}$ & - & $0.64,0.80$ & $0.25,0.73,0.80$ & $0.40,0.48,0.63,0.75$ & $0.09,0.36$ \\
\hline
\end{tabular}

EE: Ethanol Extract $\quad$ CE: Chloroform extract

Table 4. Flavonoids and tannins content of Ficus leaf extracts

\begin{tabular}{ccc}
\hline Ficus species & Total Flavonoids $\mathrm{mg}$ QE/g extract & Total Tannins mg TAE/g extract \\
\hline F. cordata $\mathrm{CE}$ & $0.036 \pm 0.004$ & $28.740 \pm 0.003$ \\
F. cordata EE & $0.082 \pm 0.017$ & $31.140 \pm 0.002$ \\
F. exasperata CE & $0.096 \pm 0.026$ & $21.248 \pm 0.037$ \\
F. exasperata EE & $0.021 \pm 0.003$ & $28.421 \pm 0.036$ \\
F. sycomorus $\mathrm{CE}$ & $0.062 \pm 0.014$ & $29.964 \pm 0.006$ \\
F. sycomorus $\mathrm{EE}$ & $0.048 \pm 0.002$ & $28.823 \pm 0.006$ \\
F. glumosa $\mathrm{CE}$ & $0.101 \pm 0.019$ & $33.758 \pm 0.004$ \\
F. glumosa $\mathrm{EE}$ & $0.063 \pm 0.002$ & $38.860 \pm 0.018$ \\
F. mucuso $\mathrm{CE}$ & $0.063 \pm 0.002$ & $44.166 \pm 0.001$ \\
F. mucuso $\mathrm{EE}$ & $0.047 \pm 0.015$ & $42.125 \pm 0.004$ \\
F. vogelli $\mathrm{CE}$ & $0.040 \pm 0.001$ & $34.982 \pm 0.001$ \\
F. vogelli $\mathrm{EE}$ & $0.059 \pm 0.003$ & $4.489 \pm 0.005$ \\
\hline
\end{tabular}




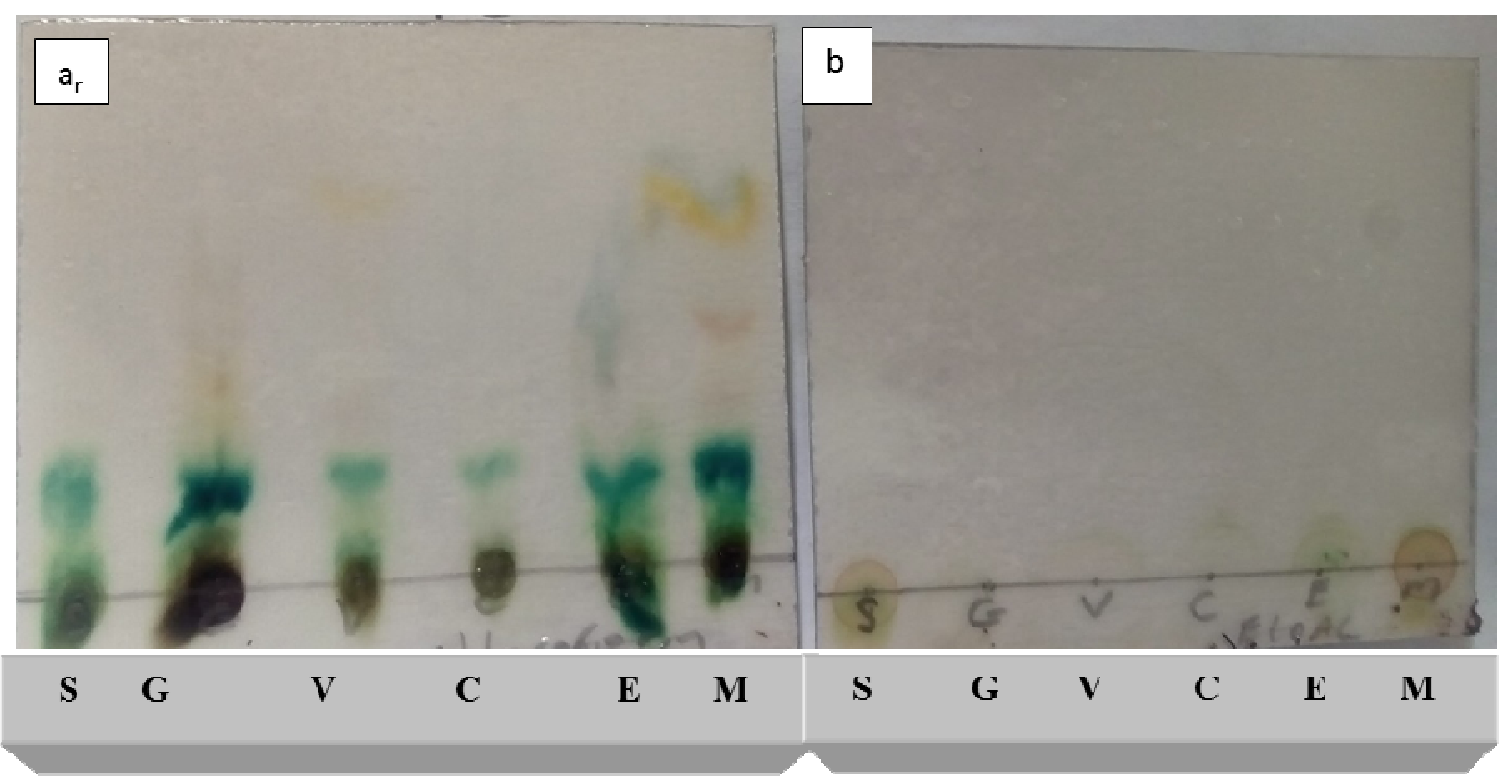

Fig. 1. TLC profile of steroids in chloroform (a) and ethanolic (b) extracts of $F$. sycomorus (S), F. glumosa (G), F. vogelli (V), $F$. cordata (C), F. exasperata (E) and F. mucuso (M)

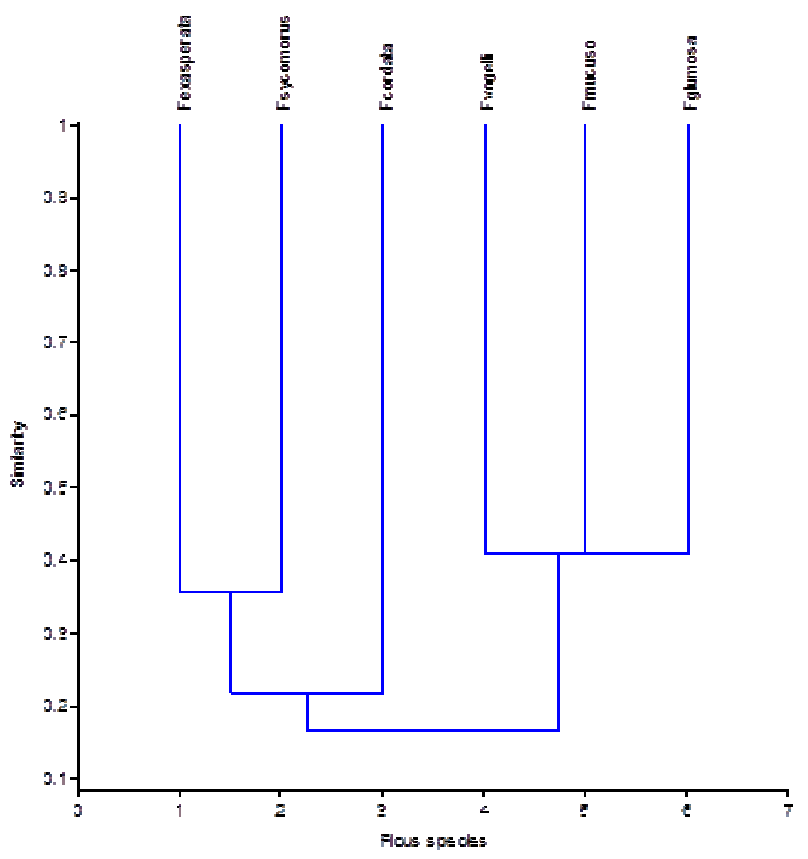

Fig. 2a. Dendrogram showing the chemotaxonomic relationship among six Ficus species from ethanolic extracts

\section{Discussion}

A sound knowledge of the chemical constituents of plants is essential not only for the discovery of therapeutic agents but also for information on the phylogenetic relationship among the taxa under consideration. Chromatographic procedure has been reported to be one of the techniques used in methods of separation of plant metabolites (Kokate et al., 2006). The Ficus species studied

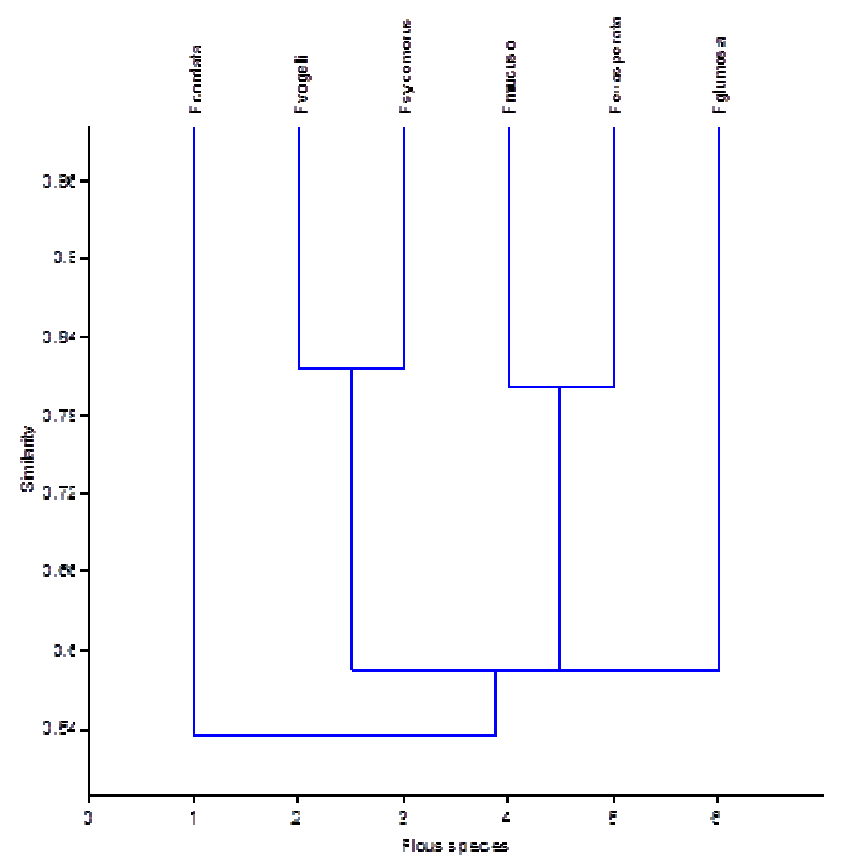

Fig. 2b. Dendrogram showing the chemotaxonomic relationship among six Ficus species from ethanolic extract

showed the presence of pharmaceutically useful classes of phytochemicals.

Phytochemicals are naturally occurring and biologically active plant compounds (Halliwell and Gutteridge, 1992) that give plants their therapeutic and pharmaceutical properties (Evans, 2002). Alkaloids are group of naturally occurring products that contain mostly basic nitrogen atoms, though usually toxic to some organisms but have pharmacological agents. Most alkaloids are used as active drugs in treatment of various diseases to treat diseases such 
254

as diabetes, cancer, cardiac dysfunction etc. and are also used as anaesthesia to relieve pain (Nicole and Cassiano, 2011).

Flavonoids constitute one of the most important groups of polyphenols used as natural antioxidant in food, medicinal and non-nutritive plant materials because of their ability to scavenge free radicals (Kim et al., 1990). Flavonoids had been reported to possess many useful pharmacological properties such as anti-inflammatory, oestrogenic, anti-allergic and antitumor activities (Larson, 1998; Tapas et al., 2008).

Saponins have been variously attributed with a diverse range of pharmacological properties such as immunostimulant, antioxidant, pesticidal, insecticidal, molluscicidal, allelopathic, protectants (Hostettmann and Marston, 1995). Some saponins are used in confectionery, as beverages and cosmetics (Price et al., 1987; Petit et al., 1995; Uematsu et al., 2000). Moreover, saponins and polyphenols had been documented to possessed hypocholestrolemic effects in both animals and humans which reduces incidence of atherosclerosis (John and Chapman, 1995; John, 1996).

Tannins, widely distributed among many plant species, are found in plant vacuoles and surface waxes (Devi et al., 2012). Studies have reported anti-inflammatory, antioxidant; antiviral, antibacterial, anti-parasitic, anticancer, antiseptic and antidiuretic properties of tannins (Souza et al., 2006; Banso and Adeyemo, 2007). The metabolite is also regarded to possess potential malaria suppressive effects through sequestration of iron and as botanical chelators (Etkins and Ross, 1982; Etkins, 1996). Tannin constituents had been reported to prevent lipid peroxidation by inhibiting cyclooxygenase activity (Zhang $e t$ al., 2004)

Steroidal compounds are of importance and play a vital role as anti-inflammatory (Cos et al., 2004; Ghaderi et al., 2014), antibacterial, antiviral and aphrodisiac agents. Certain steroids are also used in treatment of sexual dysfunction (Sunday et al., 2012).

Cardiac glycosides are also pharmacological important phytochemical used in treatment of heart related diseases e.g. Digitalis and Strophanthus species (Seigler, 1998). Antibacterial and antifungal properties due to presence of terpenoids had also been reported (Amaral et al., 1998).

The TLC profiling of both the chloroform and ethanolic extracts of the studied Ficus species confirmed the presence of number of phytochemicals. It can be inferred from the TLC profiles that chloroform (a nonpolar solvent) extracted more varieties of phytoconstituents from the leaves of Ficus species than ethanol (a polar solvent).

The occurrence and variation of secondary metabolites in Ficus species are not only important in chemotaxonomy but also in understanding the species-function relationship. Takhajatan (1973) reported that both qualitative and quantitative information on secondary metabolites are useful in taxonomic classification of plant. The presence of flavonoids, tannins, saponins, steroids and the absence of anthaquinone in all the Ficus species studied indicated that they are generic features.

Moreover, there is a general overlap in the types of secondary metabolites present in all the Ficus species studied. This could possibly explain the difficulty in devising a good infrageneric classification for the genus as earlier reported by several authors. The observations recorded in the study align with the current subgeneric, sectional and sub sectional classification schemes produced by Ogunkunle and Oladele (2008) based on foliar epidermal morphology of the members of the genus.

It was evident from this study that Ficus species contained secondary metabolites with antioxidant activity (flavonoids and tannins). This corroborates the report by Sirisha et al. (2010) that Ficus species are rich source of naturally occurring antioxidant. Therefore, the leaves of studied Ficus species are potential source of natural antioxidant that could possibly boost the antioxidant defense system in humans when consumed.

The patterns of clustering observed in the dendrogram clearly contradict the sectional classification of Croner (1965) reproduced by Sonibare et al. (2005). The species were clustered in a way that does align with classification based on morphometric analysis as done by Sonibare et al., (2004).

\section{Conclusions}

The present study revealed useful information on phytoconstituent and chemotypes variation for a better identification and classification of some Ficus species. Researches are in progress to clarify the identity of these phytoconstituents and to provide information on authentication as well as on the taxonomic relationship existing among the Ficus species.

\section{References}

Amaral JA, Ekins A, Richards SR, Knowles R (1998). Effect of selected monoterpenes on methane oxidation, dentrification and aerobic metabolism by bacteria in pure culture. Applied Environmental. Microbiology 64:520-525.

Atal CK (1982). Cultivation and utilization of aromatic plants, 1st ed, Council of Scientific and Industrial Research, New Delhi, 15-21. 10.

Banso A, Adeyemo SO (2007). Evaluation of antibacterial properties of tannins isolated from Dichrostachys cinerea. African Journal of Biotechnology 6(15):1785-1787.

Cos P, de Bruyne T, Hermans N, Apers S, Berghe DV, Vlietinck AJ (2004). Proanthocyanidins in health care: Current and new trends. Current Medicinal Chemistry 11:1345-1359.

Devi YM, Wesely EG, Johnson M (2012). Chromatographic studies on the tannins of Aerva lanata (L.) Juss. Ex Schultes. IOSR Journal of Pharmacy 2(1):041-051.

Evans WC (2002). Trease and Evans Pharmacognosy, 15th ed. WB Sauders Company Ltd. London pp 230-240.

Etkins NL (1996). Medicinal cuisiness. Diet and ethnopharmacology. International Journal of Pharmacognosy 34:313-326.

Etkins NL, Ross PJ (1982). Food as medicine and medicine as food: An adaptive framework for the international of plant utilization among the Hausa of Northern Nigeria. Social Science and Medicine 16:1559-1573.

Ghaderi P, Ahmadi R, Akbarzadeh T (2014). Flavonoid containing 
medicinal plants applied in Iranian traditional medicine for hemorrhoid treatment. International Conference on Food, Biological and Medical Sciences (FBMS-2014) Jan. 28-29. Bangkok (Thailand).

Halliwell B, Gutteridge JMC (1992). Free radicals, antioxidants and human diseases. Where are we now? Journal of Laboratory and Clinical Medicine 598-620.

Hostettmann K, Marston A (1995). Chemistry and pharmacology of natural products. Cambridge University Press. Cambridge.

Johns T (1996). Phytochemicals as evolutionary mediators of human. Nutritional physiology. International Journal of Pharmacology 34:327-334.

Johns T, Chapman L (1995). Phytochemicals ingested in traditional diets and medicines as modulators of energy metabolism. In: Arnason JT, Mata R, Romeo JT (Eds). Phytochemistry of Medicinal Plants: Recent Advances in Phytochemistry. Plenum press New York 29:161-168.

Kim JY, Germolec DR, Luster MI (1990). Panax ginseng as a potential immunodulator, studies in mice. Immunopharmacology, Immunotoxicology 12:257.

Karthika K, Jamun S, Paulsamy S (2014). TLC and HPTLC fingerprint profiles of different bioactive components from the tuber of Solena amplexicaulis. Journal of Pharmacognosy and Phytochemistry 3(1):198-206.

Kokate CK, Purohit AP, Gokhale SB (2006). In: Nirali Prakashan. Pharmacognosy, 34th ed. Pune.

Larson RA (1998). The antioxidant of higher pants. Review Article No 30. Phytochemistry 27(4):969.

Nicole MC (2011). Alkaloids: properties, applications and pharmacological effects. Nova Science Publishers, Inc. New York.

Oyedemi SO, Oyedemi BO, Arowosegbe SI, Afolayan AJ (2012). Phytochemicals analysis and medicinal potentials of hydroalcoholic extract from Curtisia dentata (Burm.f) C.A. Sm Stem Bark. International Journal of Moecular Science 13:6189-6203.

Paulsamy S, Jeeshna MV (2011). Preliminary phytochemistry and antimicrobial studies of an endangered medicinal herb Exacum Bicolor Roxb. Research Journal of Pharmaceutical, Biological and Chemical Sciences 2(4):447-457.

Petit PR, Sauvaire YD, Hillaire-Buys DM, Leconte OM, Baissac YG, Ponsin GR, Ribes GR (1995). Steroid saponins from fenugreek seeds: extraction, purification, and pharmacological investigation on feeding behavior and plasma cholesterol. Steroids 60(10):674-80.

Price KK, Johnson LI, Feriwick D (1987). The chemical and biological significance of saponins in food and feeding stuffs. Food Science and Nutrition 26:27-135.

Rasool R, Ganai BA, Akbar S, Kamili AN, Masood A (2010). Phytochemical screening of Prunella vulgaris L. - an important medicinal plant of Kashmir. Pakistan Journal of Pharmaceutical Science 23:399-402.
Rehana BH, Nagarajan N (2014). TLC and HPTLC fingerprinting of leaf extracts of Wedelia chinensis (Osbeck) Merrill. Journal of Pharmacognosy and Phytochemistry 2(6):29-33.

Seigler DJ (1998). Plants with saponins and cardiac glycosides. www.Life.VinC.Edu/plantbio/363/ saponin slides

Singh P (2010). An Introduction to Biodiversity. Ane Books Pvt, Ltd.

Singh R (2016). Chemotaxonomy: a tool for plant classification. Journal of Medicinal Plants 4(2):90-93.

Sirisha N, Sreenivasulu M, Sangeeta K, Madhusudhana Chetty C (2010). Antioxidant properties of Ficus species - A Review. International Journal of PharmTech Research 2(4):2174-2182.

Sofowora A (2006). Screening plants for bioactive agents. In: Medicinal plants and traditional medicine in Africa. 3rd ed. Spectrum Books Limited. Ibadan, Nigeria pp 150-153.

Sonibare MA, Jaiyeola AA, Egunyomi A (2004). A morphometric analysis of the genus Ficus Linn. (Moraceae). African Journal of Biotechnology 3(4):229-235.

Souza, SM, Aquino LC, Milach AC, Bandeira MA, Nobre ME, Viana GS (2006). Antiinflammatory and antiulcer properties of tannins from Myracrodruon urundeuva Allemão (Anacardiaceae) in Rodents. Phytotherapy Research 21(3):220-225.

Sun PX, Yie LK, Zhang ZL, Hu M, Lu L (1999). Colometric determination of the total content of the flavonoids in epicedium capsules. Journal of Shenyang Pharmaceutical University16:68-70.

Trease G, Evans SM (2006). Pharmacognosy. 5th ed. Bailer Tindal London pp 23-67.

Tapas AR, Sakarkar DM, Kakde RB (2008). Flavonoids as Nutraceuticals. A Review. Tropical Journal of Pharmaceutical Research 7:1099-1089.

Uematsu Y, Hirata K, Saito K (2000). Spectrophotometric determination of saponin in Yucca extract used as food additive. Journal of AOAC International 83:1451-1454.

Van-Burden TP, Robinson WC (1981). Formation of complexes between protein and tannin acid. Journal of Agricultural and Food Chemistry 1:77-79.

Wagner H, Baldt S, Zgainski EM (1996). Plant drug analysis. New York, Berlin, Springer.

Zhang YJ, DeWitt DL, Murugesan S, Nair MG (2004). Novel lipidperoxidation and Cyclooxygenase inhibitory tannins from Picrorbiza kurrora seeds. Chemistry and Biodiversity 1:426-441. 